\title{
A Short Reveiw on the Acupoints Used in Cocaine Studies
}

\author{
Bong Hyo Lee ${ }^{1}$, Sung Chul Lim ${ }^{1}$, Jae Soo Kim¹, Yun Kyu Lee ${ }^{1}$, \\ Hyun Jong Lee ${ }^{1}$, Tae Young Jung ${ }^{2}$, Sang Nam Lee ${ }^{3}$ \\ Departments of ${ }^{1}$ Acupuncture, Moxibustion, and Acupoint, ${ }^{2}$ Diagnostics, \\ ${ }^{3}$ Qigong, College of Korean Medicine, Daegu Haany University \\ 코카인 연구에 사용된 경혈에 대한 소고(小考) \\ 이봉효 ${ }^{1} \cdot$ 임성철 $^{1} \cdot$ 김재수 $^{1} \cdot$ 이윤규 $^{1} \cdot$ 이현종 $^{1} \cdot$ 정태영 $^{2} \cdot$ 이상남 $^{3}$ \\ 대구한의대학교 ${ }^{1}$ 한의과대학 침구경혈학교실, ${ }^{2}$ 진단학교실, ${ }^{3}$ 기공학교실
}

\begin{abstract}
Objectives : The aim of this study is to review the acupoints used in cocaine studies and interpret the effectiveness in an aspect of meridian theory of Korean medicine. Methods : Authors searched 50 articles in PubMed, 16 in KISS, 9 in OASIS, 40 in NDSL, and 19 in DBPIA, with the keyword of 'cocaine' or 'acupuncture'. The articles written in English only were included. The articles related with cocaine(abuse, dependence, sensitization, intake, withdrawal sign, withdrawal syndrome, reinstatement, seeking) only were subjected. The articles which used manual- or electro-acupuncture were included, and auricular was excluded. Results : The most frequently used acupoint was HT7, while LI4, LU9, ST36, and SP6 were used once respectively. HT7 could be understood to be used from the meaning of the name as well as the theory that Heart Meridian is deeply related with the brain function. LU9 seems to be used to enhance the effect of HT7. LI4 is thought to control reverting yin that flows toward the top of head following the theory of Jang Bu Sang Tong. ST36 appears to be used because it could regulate stress reaction that reverting yin is associated with. SP6 seems to have effect on brain function due to its ability to control spiritual disorder. Conclusions : The acupoints used in the cocaine studies are thought to influence the brain function through diverse mechanism, and Jang Bu Sang Tong theory seems to be involved in the mechanism, at least in part.
\end{abstract}

Key words : cocaine, acupuncture, Jang Bu Sang Tong, acupoint, meridian, addiction

\section{Introduction}

Cocaine is well known as a representative drug of abuse. Although the reason why cocaine must be a dangerous substance can not be explained briefly, its strong reinforcing effect is must take an important part. The reinforcing effect of cocaine is known to be related with the inhibition of re-uptake of dopamine released in the synapse of mesolimbic system including nucleus accumbens. This effect is easy to result in dependence and abuse, which eventually drives subjects to the repeated use and addiction.

Acupuncture, a representative treatment of eastern Asia

Received June 26, 2013, Revised August 7, 2013, Accepted September 2, 2013

Corresponding author: Bong Hyo Lee

Department of Acupuncture, Moxibustion and Acupoint, College of Korean Medicine, Daegu Haany University, 165 Sang-dong, Suseong-gu, Daegu 706-828, Korea

Tel: +82-53-770-2252, Fax: +82-53-768-6340, E-mail: rjscjs31@hanmail.net

This research was supported by a grant from Daegu Haany University Ky · lin Foundation in 2012 (2012-901-20).

(c) This is an open access article distributed under the terms of the Creative Commons Attribution Non-Commercial License (http://creativecommons.org/licenses/ by-nc/3.0) which permits unrestricted non-commercial use, distribution, and reproduction in any medium, provided the original work is properly cited. 
like Korea and China has been used widely for a long time for diverse disease including substance abuse. Nowadays, acupuncture became a brilliant therapy in the treatment of drug addiction ${ }^{1,2)}$ already. In this atmosphere, a number of researchers have tried to reveal the effectiveness of acupuncture and some evidences has been reported that it could be useful for the treatment of drug addiction. However, the studies have just explained the effectiveness of acupuncture using neuronal or molecular pathway of western medicine and not mentioned detail reason why the acupoints had been selected.

So, the authors investigated cocaine studies that had used acupuncture and reviewed the effectiveness of acupoints on the viewpoint of meridian theory.

\section{Materials and Methods}

\section{Materials}

1) The authors searched 50 articles in PubMed(US National Library of Medicine National Institutes of Health, http://www.ncbi.nlm.nih.gov/sites/entrez?db=pubmed) using keywords of 'cocaine, acupuncture', and selected 5 articles among them. Also, 16 articles were searched in KISS (Koreanstudies Information Service System, http://search. koreanstudies.net/) using 'cocaine' and 3 articles were selected. And 9 articles were searched in OASIS(Korea Institute of Oriental Medicine, http://oasis.kiom.re.kr/main. jsp) using 'cocaine'and 1 article was selected. In NDSL(National Discovery for Science Leaders, http://scholar.ndsl.kr/ index.do), 40 articles were searched using 'cocaine and acupuncture', and 5 articles were selected. In DBPIA(Nurimedia, http://www.dbpia.co.kr/), 19 articles were searched using 'cocaine' and no article was selected.

2) Articles written in English only were subjected.

3) Articles focused to the addiction including abuse, dependence, sensitization, intake, withdrawal sign, withdrawal syndrome, reinstatement, seeking were included.

4) Articles using body acupuncture(manual or electrical) only were treated, and auricular acupuncture and bee venom acupuncture were excluded.

5) Both of experimental and clinical research were reviewed.

6) According to the process above, 7 studies were subjected finally.

\section{Methods}

We reviewed the acupoints used in the subjects and analyzed the reason why the points were used on the viewpoint of meridian and collateral theory.

Table 1. Acupoints Used in the Cocaine Studies and Their Effects

\begin{tabular}{|c|c|c|c|}
\hline Model(Disease) & Effect & $\begin{array}{l}\text { Used- } \\
\text { acupoint }\end{array}$ & $\begin{array}{l}\text { Country of } \\
\text { corresponding author }\end{array}$ \\
\hline $\begin{array}{l}\text { Methadone-maintained } \\
\text { dependence }\end{array}$ & $\begin{array}{l}\text { Suppression of urine toxicology(positive for cocaine), amount of } \\
\text { cocaine use, frequency of cocaine use, craving, depression, } \\
\text { intensity of drug and legal problems, somatization, anxiety, } \\
\text { phobic anxiety, psychoticism in patients }\end{array}$ & $\begin{array}{l}\mathrm{LI} 4 \\
\text { (combined } \\
\text { with auricular) }\end{array}$ & $\mathrm{USA}^{3)}$ \\
\hline Sensitization & $\begin{array}{l}\text { Suppression of locomotor activity and tyrosine hydroxylase } \\
\text { immunoreactivity induced by cocaine in rats }\end{array}$ & HT7 & Korea ${ }^{4)}$ \\
\hline \multirow[t]{2}{*}{ Intake } & $\begin{array}{l}\text { Suppression of cocaine intake and extracellular dopamine } \\
\text { release in the nucleus accumbens in rats }\end{array}$ & HT7 & Korea $^{5)}$ \\
\hline & Suppression of cocaine taking behavior in rats & $\begin{array}{l}\text { HT7-LU9 } \\
\text { HT7 }\end{array}$ & $\begin{array}{l}\text { Korea }^{6)} \\
\text { Korea }^{7)}\end{array}$ \\
\hline Reinstatement & $\begin{array}{l}\text { Suppression of reinstatement of cocaine-seeking behavior as } \\
\text { well as c-Fos and pCREB induced by cocaine in the nucleus } \\
\text { accumbens in rats }\end{array}$ & HT7 & Korea $^{8)}$ \\
\hline Obesity & $\begin{array}{l}\text { Increase of the reduction of cocaine and amphetamine-regulated } \\
\text { transcript peptide in arcuate nucleus in rats } \\
\text { Suppression of body weight and energy intake }\end{array}$ & $\begin{array}{l}\text { ST36-SP6 } \\
\text { (electro } \\
\text { acupuncture) }\end{array}$ & China $^{9)}$ \\
\hline
\end{tabular}




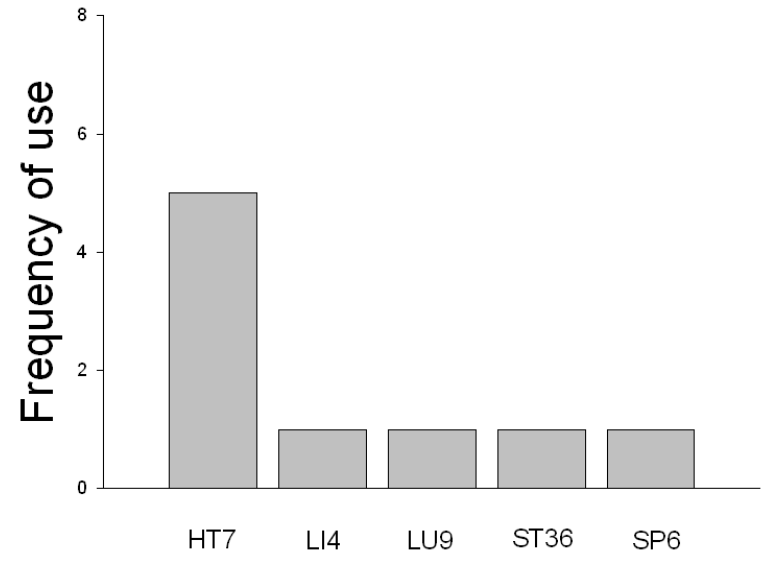

Fig. 1. The frequency of use of the acupoints.

\section{Results}

\section{Acupoints used in the cocaine study}

The acupoints used in the cocaine researches are as follow(Table 1).

\section{Frequency of use of acupoints}

In the cocaine researches reviewed in this study, HT7 was used the most frequently(5 times) and the other points(LI4, LU9, ST36, SP6) were used once(Fig. 1).

\section{Theme of studies}

Almost of cocaine studies with acupuncture belong to behavioral study using rats, and the studies evaluating the effectiveness of acupuncture on the intake behavior appeared the most frequently.

\section{Discussion}

\section{Review on the acupoints used for cocaine study}

1) HT7: HT7 is the Source point and Earth point as well as Sedation point of Heart Meridian. This point is usually used to treat the disturbance of the spirit, and it is one of the specific acupoints selected for the emotional problems associated with the function of heart ${ }^{10)}$. In Korean medicine, the functions of brain and spirit are related with Heart. This theory is supported by the Eight Constitutional Acupuncture Treatment which uses many acupoints of Heart Meridian for the treatment of mental diseases and Tae Geuk Acupuncture Treatment which uses acupoints of Heart Meridian for the diagnosis and treatment of 4 type of constitution. In addition, the HT7's name 'Shinmun' means the gate of spirit and mental ability. The report of Lee et al. ${ }^{11)}$ that HT7 could suppress the c-Fos expression and the locomotor activity induced by acute cocaine also seems to be parallel with this function of HT7. So, it looks like reasonable to use HT7 for the drugs of abuse such as cocaine.

2) LI4: LI4 is the Source point of Large Intestine Meridian which belongs to yang brightness. This point is able to attenuate heat, lower muscular tension, reduce pain, calm the mind, suppress interior wind, and tonify blood ${ }^{10)}$. Yang brightness is known to be related with the mental disorder ${ }^{12)}$. This is thought because it could be able to regulate the function of brain through the control of reverting yin that flows to the top of the head. So, the reports of some studies $^{13,14)}$, that have demonstrated that acupuncture at LI4 could normalize the blood stream in the brain appear to be reasonable. As well, it is one of the acupoints used for acupuncture anesthesia ${ }^{15)}$ and this effect is also thought to be supported by this mechanism.

3) LU9: LU9 is the gathering point for the blood vessels as well as the Source point of Lung Meridian which belongs to greater yin. One of the aims that this point is usually used for is to control of the blood vessels ${ }^{10)}$. Jeon et al. ${ }^{6}$ reported that LU9 produced the synergy effect with HT7 on suppressing cocaine intake. According to the special $\mathrm{Co}^{-}$ nnection between viscera and bowel called Jang Bu Sang Tong ${ }^{16}$, greater yin is linked to greater yang which is on the opposite site of lesser yin. So, LU9 might be exert its function on the brain by influencing HT7's function through regulation of the balance bewteen greater yang and lesser yin. However, the effect of LU9 alone was not as powerful as HT7. It appears because LU9 does affect the brain indirectly, compared to HT7.

4) ST36-SP6: ST36 and SP6 points were used simultaneously owing to electro-acupuncture. 
ST36 is the Accumulation point of Stomach Meridian ${ }^{10)}$ which belongs to yang brightness, and according to Jang $\mathrm{Bu}$ Sang Tong ${ }^{16}$, yang brightness is linked to reverting yin which Pericardium Meridian belongs to. In Korean medicine, reverting yin is related to the emotion- and stress-induced problems and antagonizes lesser yin. So, the acceleration of Pericardium Meridian often inhibits Heart Meridian involved in the regulation of brain function. This mechanism is thought to underlie a little of tonic or tension-type diseases. Therefore, the effect of ST36 on the cocaine addiction might, at least in part, be produced through the regulation of the balance between reverting yin and lesser yin.

Actually, many studies ${ }^{17-20)}$ have demonstrated that electroacupuncture at ST36-SP6 could affect the stress reaction.

Interestingly, other studies have suggested some evidences that acupuncture at ST36 could influence brain. Cho reported that ST36 regulated blood stream of brain ${ }^{21)}$ and Kim et al. have shown that ST36 could affect the vitality of specific area in brain ${ }^{22)}$.

So, it seems that ST36 might play its role on the cocaine addiction through the control of Pericardium and Heart Meridian that ST36 is linked to, and related indirectly, respectively.

SP6 belongs to Spleen Meridian and the crossing point of Spleen, Liver and Kidney Meridians. This point enhances and holds in the blood, calms the mind, moves the blood, stops pain and regulates the circulatory system ${ }^{10}$. SP6 takes part in the control of blood stream as one of the Eum Yang Yi Chong Hyul, and in Korean medicine, the spiritual and mental disorder could be influenced by the blood.

In addition to the cocaine addiction, Hong et al's fMRI study ${ }^{23)}$ has shown that electroacupuncture at SP6 could regulate the vitality of the specific region of brain.

So, it looks like reasonable that SP6 had been used in cocaine study.

Also, some evidence ${ }^{24)}$ showing that sugar addiction and drug dependence share the neuronal pathways of dopamine and endorphine has been suggested. This result might imply that appetite in related with drug abuse. Therefore, electroacupuncture at ST36-SP6 seems to have effects on the reward system of brain through regulating Stomach Meridian and Spleen Meridian which are generally used to control the desire for food.

Taken together, using electroacupuncture at ST36-SP6 for cocaine addiction seems to make sense, and it is likely that its effect is mediated by the control of the balance between reverting yin and lesser yin that may be regulated by yang brightness through the connection of Jang Bu Sang Tong.

\section{Tendency of selecting acpuoints}

It is interesting that there is a tendency in the choice of acupoints. That is, HT7 point was selected by Korean researchers only, while Chinese preferred ST36-SP6. Also, in Korean studies, the most of acupuncture was manual, while Chinese performed electroacupuncture. Although it is true that the subjects reviewed in this study is very small, but obviously, we could see that a preference of selecting acupoints according to the country is exist.

\section{Conclusion}

As a conclusion, HT7 was used the most frequently and LI4, LU9, ST36, SP6 have also been shown in the cocaine studies. The aucpoints belong to lesser yin, yang brightness and greater yin. LU9 is likely to be used to support HT7's effect, and ST36-SP6 only was used for electroacupuncture. Commonly, the acupoints seem to have their effect on the brain function, and the mechanism underlying this effect may be interpreted using Jang Bu Sang Tong theory of Korean medicine.

\section{Acknowledgements}

This research was supported by a grant from Daegu Haany University Ky $•$ lin Foundation in 2012 (2012-901-20). 


\section{References}

1. Bullock ML, Umen AJ, Culliton PD, Olander RT. Acupuncture treatment of alcoholic recidivism: a pilot study. Alcohol Clin Exp Res. $1987 ; 11: 292-5$.

2. NIH Consensus Conference. Acupuncture. JAMA. 1998 ; 280 : 1518-24.

3. Avants SK, Margolin A, Chang P, Kosten TR, Birch S. Acupuncture for the treatment of cocaine addiction. investigation of a needle puncture control. J Subst Abuse Treat. 1995; 12 : 195-205.

4. Lee B, Han SM, Shim I. Acupuncture attenuates cocaine-induced expression of behavioral sensitization in rats: Possible involvement of the dopaminergic system in the ventral tegmental area. Neurosci Lett. 2009 ; 449 : 128-32.

5. Lee HI, Kim MR, Kim SY, Shim IS, Han SW, Jin CB, et al. Acupuncture attenuates cocaine-induced dopamine release in the nucleus accumbens and voluntary cocaine intake in rats. J Korean Acupuncture and Moxibustion Society. 2003 ; 20 : 170-9.

6. Jeon HJ, Lee BH, Lee KM, Kim JS, Lee YK, Lee JH, et al. A synergy effect of combination of acupoints in cocaine take. J Korean Acupuncture and Moxibustion Society. 2010 ; 27 : 31-41.

7. Lee BH, Kim SH, Lim SC, Kim JS, Lee YK, Lee JH, et al. Suppression of cocaine intake by acupuncture at HT7. J Korean Oriental Medicine. $2010 ; 31: 17-27$.

8. Yoon SS, Yang EJ, Lee BH, Jang EY, Kim HY, Choi SM, et al. Effects of acupuncture on stress-induced relapse to cocaineseeking in rats. Psychopharmacol. $2012 ; 222$ : 303-11.

9. Tian DR, Li XD, Wang F, Niu DB, He QU, Li YS, et al. Up-regulation of the expression of cocaine and amphetamine- regulated transcript peptide by electroacupuncture in the arcuate nucleus of diet-induced obese rats. Neurosci Lett. 2005 ; 383 : 17-21.

10. Ross J. Acupuncture point combinations: The key to clinical success. Philadelphia : Churchill Livingstone. 1995 : 213-7, 231-3, 277-9, 299-300, 306-8.

11. Lee BB, Shim IS, Yang CH, Lee HI, Hahm DH, Lee HJ. Effect of acupuncture(HT7) on acute cocaine-induced locomotor activity and fos-like immunoreactivity in the brain of the rats. J
Korean Meridian \& Acupoint. $2002 ; 19: 25-33$.

12. Chi SI. Korean-English translation \& elucidation of Shang han luon. Seoul : Haenglim Publishing Company. 2004 : 299-306.

13. Mun HC, Hwang WJ, Lee GM, Cho JW, Oh HH, Byun JY, et al. The nuclear medical study on the effect of li4 acupucture on cerebral blood flow. J Korean Acupuncture and Moxibustion Society. $2001 ; 18: 46-54$.

14. Lee GM, Hwang YJ, Yang YS, Kim SJ, Lyu DS, Kim MJ, et al. The nuclear medical study on the effect of Hap - Kok(LI4) Acupuncture on cerebral blood flow. J Korean Acupuncture and Moxibustion Society. 2001; 18 : 93-104.

15. The committee for publish of meridian and acupoint textbook. Meridian and Acupoint of College (Ant.) 5th ed. Wonju : Euibang Publishing Company. 2010 : 75.

16. Lee BH, Kim SJ, Jung CH, Kwon SY, Lim SC, Lee KM, et al. A study on the basic principle of the classification of sidong disease, sosaeng disease. J Korean Acupuncture and Moxibustion Society. $2008 ; 25: 43-57$.

17. Jeong EW, Kim HS, Lee SK, Kim MS, Cho ZH, Sung KK. Effects of electroacupuncture on plasma stress hormone responses to acute and chronic immobilization stress. J Korean Acupuncture and Moxibustion Society. 2010 ; 27 : 105-15.

18. Lim SK, Lee DH, Kwon YJ, Lee JC, Jung CJ, Kim YS, et al. Effects of fixed-intensity and varied-intensity electroacupuncture on heart rate variability in healthy people with stress task. J Korean Acupuncture and Moxibustion Society. $2011 ; 28$ : 107-16.

19. Jo MH, Choi BT, Jang KJ. The Effects of $120 \mathrm{~Hz}$ High frequency electroacupuncture on the cold-restraint-induced gastric mucosal damages. J Korean Acupuncture and Moxibustion Society. $2003 ; 20: 177-93$.

20. Lee CH, Kim YH, Song BY, Yug TH. Expression of neurotransmitter(CRF, CRF-R and CRF-BP) related to stress in stomach and zusanli in rats. J Korean Acupuncture and Moxibustion Society. $2003 ; 20: 89-102$.

21. Cho NG. Effect of Acupuncture Treatment at ST 36 on the Blood Pressure and Cerebral Hemodynamics of Rats. J Korean Acupuncture and Moxibustion Society. 1999 ; $16: 307-19$.

22. Kim YI, Kim YH, Im YG, Lee H, Lee BL, Kim YJ. A fMRI study on the cerebral activity induced by Electro-acupuncture on $\mathrm{Zu}-$ sanli(St36). J Korean Acupuncture and Moxibustion Society. 
$2003 ; 20: 133-50$.

23. Hong KE, Lee BR, Lee H, Yim YK, Kim YJ. fMRI study on the cerebral activity induced by Electro-acupuncture on Sanyinjiao(Sp6). J Korean Acupuncture and Moxibustion Society. 2003 ;
$20: 86-103$

24. Fortuna JL. Sweet preference, sugar addiction and the familial history of alcohol dependence: shared neural pathways and genes. J Psychoactive Drugs. $2010 ; 42: 147-51$.

\section{국문초록}

목적 : 본 연구는 코카인 연구에 사용된 경혈을 고찰하고 그 효능을 경락학설의 관점에서 해석하기 위해 수행되었다. 방법 : 논문 검색 사이트 PubMed에서 50 개의 논문, KISS에서 16 개의 논문, OASIS에서 9 개의 논문, NDSL에서 40 개의 논문, DBPIA에서 19 개의 논문을 '코카인' 또는 '침'을 검색어로 하여 조사하였다. 영문로 작성된 코카인(남용, 의존, 민감화, 섭취, 금단 증상, 재발, 탐닉)에 관한 논문을 조사하였고 수기 침이나 전침만을 대상으로 하였으며 이침은 제외하였다. 결과 : 가장 많이 이용된 경혈은 신문(HT7)이었고 합곡(LI4), 태연(LU9), 족삼리 (ST36), 삼음교(SP6) 등은 한 번씩 사용되었다. 신문은 수소음심경이 뇌의 기능과 깊이 관련되어 있다는 것 및 혈명이 가지는 뜻으로부터 충분 히 이해될 수 있으며 태연은 신문의 효능을 증강시키는 것으로 생각된다. 합곡은 머리 꼭대기로 흐르는 궐음경을 조절하는 것으로 생각되고 족삼리는 궐음과 관련된 스트레스 반응을 조절하는 것으로 보이며 삼음교는 정신질환에 효능이 있으므로 뇌 기능을 조절하기 위해 사용된 것으로 생각된다. 결론 : 코카인 연구에 사용된 경혈은 다양한 경로를 통해 뇌 기능에 영향을 주는 것으로 사료되며 장부상통 이론이 일정 부분 관련되어 있는 것으로 생각된다. 